\title{
KECAKAPAN SISWA DALAM PEMODELAN MATEMATIKA
}

Hotman Marbun

Universitas Negeri Medan

hotmanmarbun5@gmail.com

Melyana Harahap

Universitas Negeri Medan

harahapmelyana@gmail.com

Riska Syahdia

Universitas Negeri Medan

riskanst2903@gmail.com

Salomo Banjarnahor

Universitas Negeri Medan

banjarnahorsalomo@gmail.com

\section{Abstrak}

Jurnal ini bertujuan untuk memberikan hasil kajian untuk acuan/rujukan untuk menunjukkan kemampuan siswa dalam pemodelan matematika. Pemodelan merupakan salah satu hal yang ditekankan akhir-akhir ini, seperti dilihat pada contoh soal-soal dalam perhitungan yang sering memerlukan pemodelan untuk penyelesaianya. Merupakan titik ukur bagi siswa dalam memahami materi matematika. Pemodelan dalam matematika memiliki siklus yang terdiri dari empat tahapan utama, yakni permasalahan yang nyata, membuat model realistis, dan model matematika, dan menentukan solusi permasalahan. Kemampuan dalam pemodelan dapat dilihat melalui proses representasi masalah sehari-hari ke dalam bentuk matematis dengan menggunakan simbol matematis, sehingga dapat membangun model situasi penyelesaian. Siswa yang memiliki kemampuan dalam menggunakan simbol dapat dikatakan memiliki kemampuan abstraksi. Penggunaan simbol pada proses abstraksi berfungsi sebagai alat komunikasi khususnya dalam menjelaskan konsep atau ide yang dimiliki, sehingga hal ini dapat digunakan dalam memecahkan masalah matematika. Dengan kata lain, kemampuan abstraksi merupakan 
kemampuan yang digunakan untuk membangun pemodelan dalam matematika. Siswa yang memiliki kemampuan abstraksi yang baik akan lebih mudah memahami permasalahan konkret melalui operasi dengan simbol dan sistem simbol. Sehingga, dengan kemampuan ini diharapkan dapat mempermudah siswa dalam menggunakan model matematika untuk menyelesaikan permasalahan sehari-hari.

\title{
Kata kunci : pemodelan matematika, kemampuan abstraksi
}

\begin{abstract}
Abstrak
This journal aims to provide study results for reference to show students' abilities in mathematical modelling. Modelling is one of the things that is emphasized lately. As seen in the examples of questions that often require modelling to solve. It is a measuring point for students in understanding mathematical material. Modelling in mathematics has a cycle consisting of four main stages, namely real problems, making realistic models, and mathematical models, and determining problem solutions. The ability in modelling can be seen through the process of representing everyday problems into mathematical form using mathematical symbols, so that they can build models of settlement situations. Students who have the ability to use symbols can be said to have abstraction abilities. The use of symbols in the abstraction process serves as a communication tool, especially in explaining concepts or ideas they have, so that they can be used in solving mathematical problems. In other words, abstraction ability is the ability that is used to build modelling in mathematics. Students who have good abstraction skills will more easily understand concrete problems through operations with symbols and symbol systems. So, with this ability, it is hoped that it will make it easier for students to use mathematical models to solve everyday problems.
\end{abstract}




\section{PENDAHULUAN}

Berdasarkan Peraturan Menteri Pendidikan dan Kebudayaan No. 22 Tahun 2016 tentang standar proses bahwa salah satu prinsip pembelajaran pada kurikulum 2013 adalah merubah pembelajaran dari verbalisme menuju keterampilan aplikatif (Kemendikbud, 2016). Sehingga dalam ilmu matematika, pemodelan merupakan suatu konsep yang mendukung prinsip tersebut. Hal itu terdapat dalam tes PISA oleh OECD yang mana framework dari soal PISA adalah mathematical Literacy. Pada literasi matematika siswa diharapkan untuk dapat menerapkan apa yang di peroleh dari sekolah dan diterapkan dalam kehidupan sehari-hari dalam berbagai situasi (OECD, 2013). Pentingnya menghubungkan matematika dengan kehidupan sehari-hari menurut Febrian (2016) adalah untuk mengubah paradigma yang menyatakan bahwa pengetahuan siswa yang didapat disekolah dan pengalaman sehari-hari siswa tidak memiliki koneksi. Berdasarkan tuntutan dalam pembelajaran matematika tersebut dapat disimpulkan bagaimana pentingnya kemampuan siswa dalam menerapkan pengetahuan yang didapat disekolah ke dalam masalah nyata.

Menurut Ang (2001) proses mengubah atau mewakili masalah dalam dunia nyata kedalam bentuk matematika dalam upaya untuk menemukan solusi dari suatu masalah disebut dengan pemodelan matematika. Kemudian menurut Maß (2006) kompetensi dalam pemodelan mencakup keterampilan dan kemampuan untuk melakukan proses pemodelan secara tepat dan berorientasi pada tujuan. Yang selanjutnya kompetensi pemodelan tersebut dirumuskan menjadi beberapa indikator oleh Maaß (2006) yang kemudian digunakan dalam penelitian ini yaitu (1) memahami masalah sebenarnya, (2) menyiapkan model matematika dari model nyata, (3) menyelesaikan soal matematika dalam model matematika dan (4) menafsirkan hasil matematika dalam situasi nyata.

Ada beberapa sekolah khususnya Sekolah Menengah Atas (SMA) yang hanya mengajarkan materi yang kaku, tidak di barengi dengan pendalaman materi, juga konsep abstrak yang begitu penting untuk siswa/siswi ke depannya. Kemampuan abstraksi ialah bagian dari proses pemodelan matematika yang diwujudkan dalam bentuk keterampilan penggunaan simbol dan sistem simbol. Hal ini dapat dilihat dari tahapan siklus pemodelan. Pada siklus tersebut, diperlukan kemampuan abstraksi terkait mempresentasikan bahasa verbal dalam masalah nyata 
menjadi bahasa matematis dengan penempatan simbol-simbol yang tepat (Fevi Rahmawati, Tobondo \& Riskiningtyas, 2017: 306).

Menurut Killpatrick (2001) kecakapan siswa/siswi dalam pemodelan matematika ini tidak terlepas dari kemampuan seperti 1) pemahaman konseptual (conceptual understanding); 2) kelancaran prosedural (procedural fluency); 3) kompetensi strategis (startegic competence); 4) penalaran adaptif (adative reasoning); 5) disposisi produktif (productive disposition). Kecakapan matematis diperlukan sebagai satu syarat mencapai kemajuan di zaman modern, dan sebagai bekal untuk mengahadapi abad ke-21 yang serba kompetitif (Kilpatrick, 2001).

Model matematika digunakan tidak hanya dalam ilmu matematika, tetapi banyak disiplin ilmu dan bidang studi yang berbeda. Kita dapat mencari aplikasi model matematika di bidangbidang seperti fisika, ilmu biologi, kedokteran, teknik, ilmu sosial dan politik, ekonomi, bisnis, dan keuangan, juga problem-problem jaringan komputer. Tentunya bidang dan tipe aplikasi yang berbeda menghendaki bidang-bidang matematika yang berbeda (Widowati \& Sutimin, 2003: 1).

\section{METODE PENELITIAN}

Penelitian ini merupakan penelitian deskriptif dengan menggunakan pendekatan kualitatif. Metode yang digunakan pada penelitian ini adalah survey dengan menggunakan kuesioner jenis hand-delivered survey. Penentuan subjek pada penelitian ini menggunakan teknik purpossive yaitu teknik pengambilan data dengan pertimbangan dan tujuan tertentu (Prastowo, 2012: 197). Subjek pada penelitian ini yaitu seluruh siswa/siswi yang mengisi kuesioner yang telah disebar. Penelitian ini dilakukan pada bulan Oktober 2021. Metode pengumpulan data yang digunakan dalam penelitian ini diperoleh melalui data kuesioner (angket). Analisis data pada penelitian ini menggunakan analisis kualitatif, berupa pengumpulan data, reduksi data, penyajian data, dan penarikan kesimpulan. Langkah untuk menganalisis data hasil tes tertulis adalah menentukan nilai tes siswa dan menentukan kategori kemampuan pemodelan matematika siswa 
Tabel 1. Kategori kemampuan pemodelan matematika siswa (Jurnal Gantang III (2) (2018):73-81)

\begin{tabular}{|lc|}
\hline Rentang Nilai Siswa & $\begin{array}{c}\text { Kategori Kemampuan } \\
\text { Pemodelan }\end{array}$ \\
\hline $\mathbf{8 0} \leq \boldsymbol{T} \leq \mathbf{1 0 0}$ & Sangat Baik \\
\hline $\mathbf{6 0} \leq \boldsymbol{T}<\mathbf{8 0}$ & Baik \\
\hline $\mathbf{4 0} \leq \boldsymbol{T}<\mathbf{6 0}$ & Cukup \\
\hline $\mathbf{2 0} \leq \boldsymbol{T}<\mathbf{4 0}$ & Kurang \\
\hline $\mathbf{0} \leq \boldsymbol{T}<\mathbf{2 0}$ & Sangat Kurang \\
\hline
\end{tabular}

\section{HASIL DAN PEMBAHASAN}

Untuk soal No 1, dari enam orang yang siswa SMA yang menjadi responden penelitian kami, seluruh siswa menjawab soal yang telah dimodelkan dengan benar, dengan kata lain persentase siswa menjawab benar sebesar 100\% (Sangat Baik).

Untuk soal No. 2, dari enam orang yang siswa SMA yang menjadi responden penelitian kami. Sebanyak empat orang menjawab benar, dan dua orang lainnya menjawab salah. Kesalahan yang dilakukan siswa yang menjawab dikarenakan kurang teliti dalam memodelkan dan siswa juga kurang mengetahui cara memodelkan persoalan matematika yang lumayan rumit. Sehingga persentase siswa menjawab benar sebesar 66,7 \% (Baik).

Untuk soal No 3, dari enam orang yang siswa SMA yang menjadi responden penelitian kami, seluruh siswa menjawab soal yang telah dimodelkan dengan benar, dengan kata lain persentase siswa menjawab benar sebesar 100\% (Sangat Baik).

Untuk soal No 4, dari enam orang yang siswa SMA yang menjadi responden penelitian kami, seluruh siswa menjawab soal yang telah dimodelkan dengan benar, dengan kata lain persentase siswa menjawab benar sebesar 100\% (Sangat Baik). 
Untuk soal No.5 diatas, dari enam orang siswa SMA yang menjadi responden penelitian kami, seluruh siswa berhasil memodelkan dan menyelesaikan soal dengan jawaban yang benar. Dengan kata lain persentase siswa yang menjawab benar sebesar $100 \%$ (Sangat Baik).

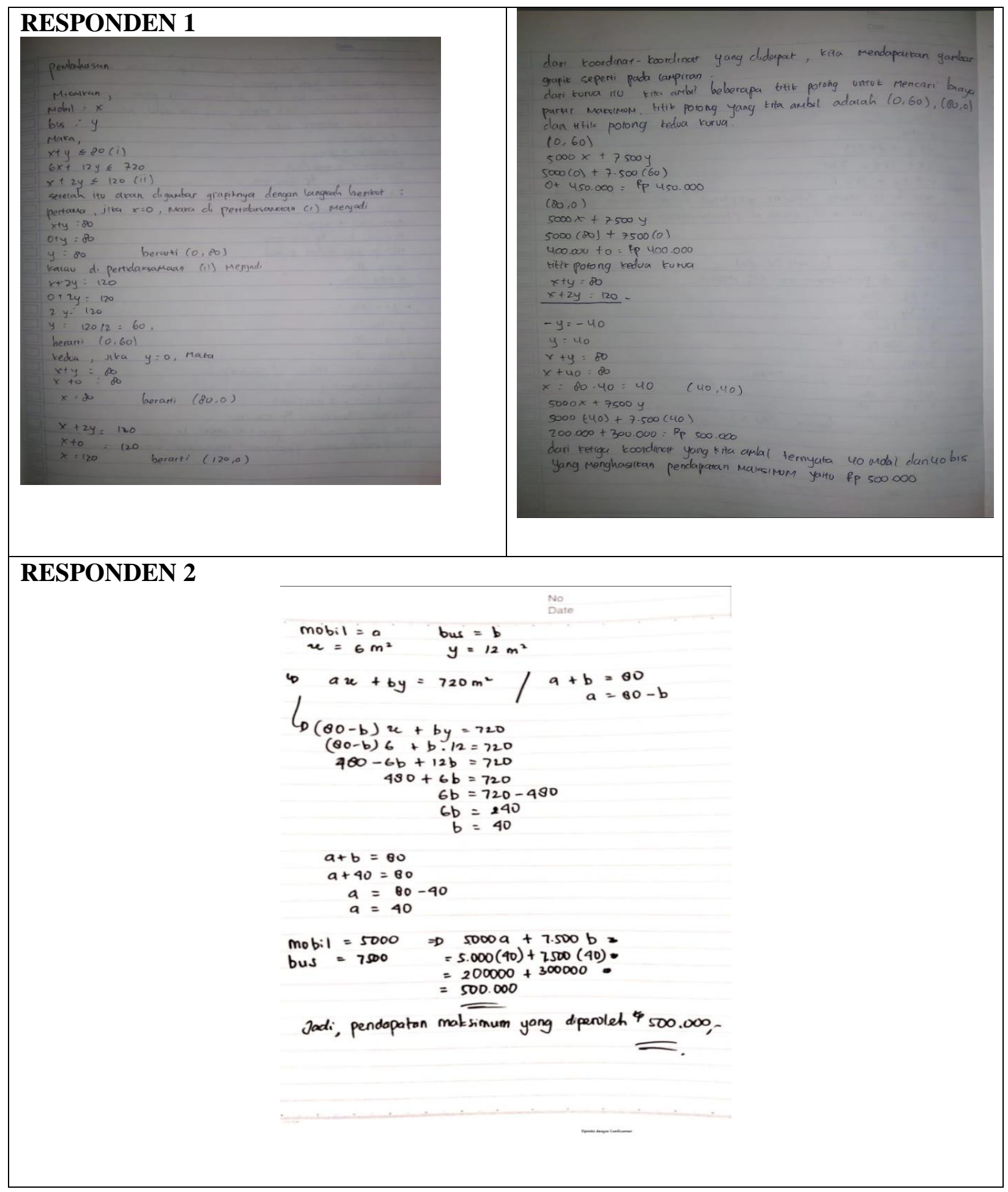




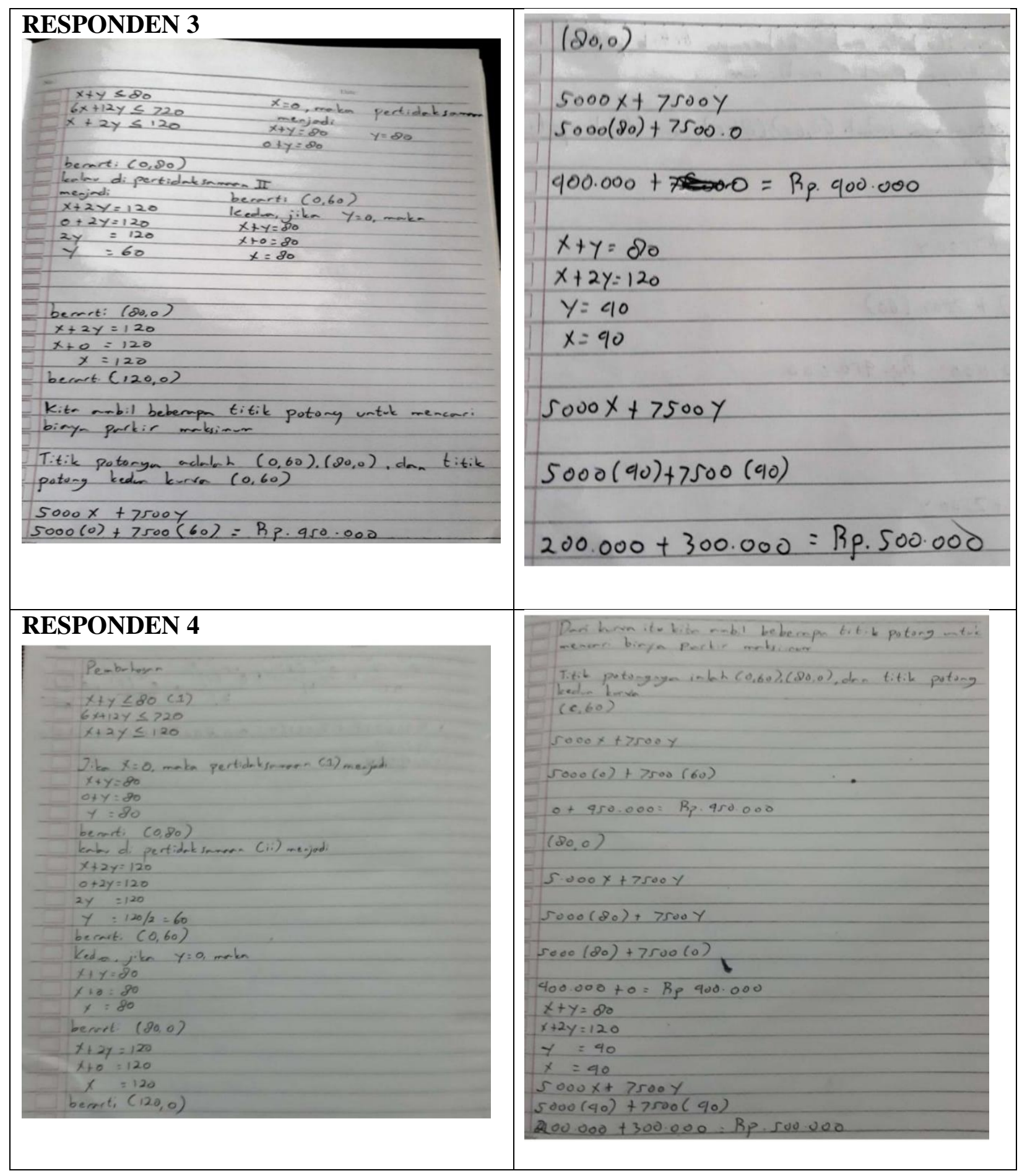




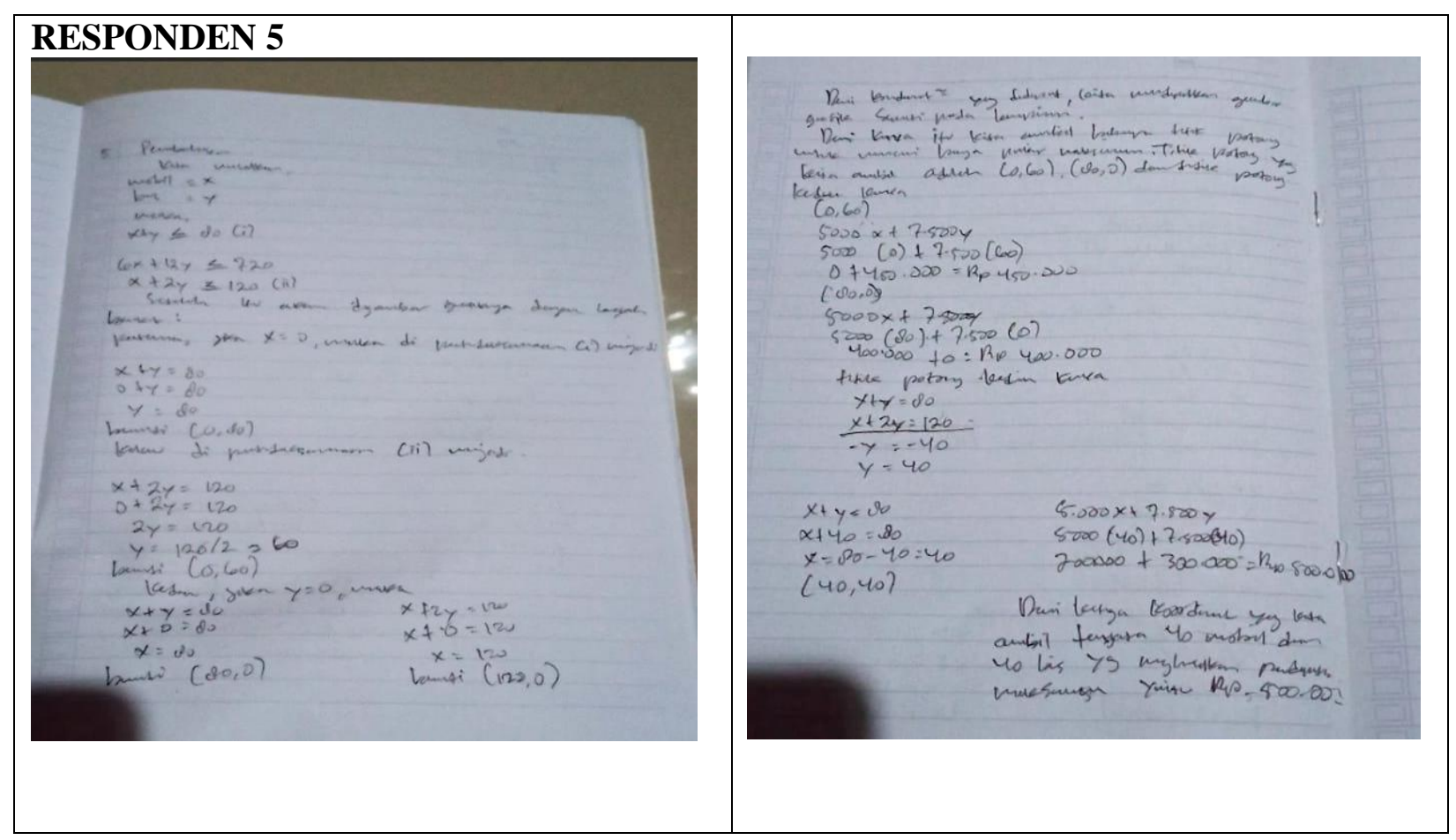

Dari jawaban para siswa yang telah dianalisis, maka kesalahan yang dilakukan beberapa subjek disebabkan oleh hal-hal berikut:

a. Siswa Kurang teliti dalam pengelompokan data/variabel. Mereka salah dalam menuliskan kembali pemodelan matematikan dari soal. Sehingga ketika dikerjakan, jawaban yang di dapat terjadi kesalahan.

b. Siswa tidak mampu menggambarkan situasi permasalahan, sehingga siswa mengalami kesulitan dalam membuat model matematika dan penggunaan rumus untuk dimodelkan jadi keliru.

Berdasarkan penelitian yang kami lakukan terhadap para responden yaitu siswa SMA mengenai Kecakapan Siswa dalam Pemodelan Matematika, kami berusaha mengumpulkan data yang faktual dengan cara menyebarkan kuisioner yang berisi lima soal terkait pemodelan matematika kepada para siswa yang duduk dibangku SMA. Dari hasil kuisioner yang kami sebarkan, para responden hampir mencapai hasil yang sempurna dalam menyelesaikan soal-soal terkait pemodelan matematika. Dari lima soal yang kami bagikan kepada 6 orang responden, terdapat 4 orang siswa mengerjakan dengan persentase nilai $100 \%$ a, dan 2 orang lainnya menjawab dengan persentase nilai $80 \%$ atau dengan kata lain dari hasil kedua siswa ini, 
kesalahan dalam menyelesaikan soal pemodelan hanya 1 dari 5 soal yang diberikan. Sehingga apabila dirata-ratakan persentase kecakapan para responden dalam memodelkan matematika adalah $(4 \times 100)+(2 \times 80) / 6=93,33 \%$ (sangat baik).

Sehingga dari hasil analisa diatas, kita mampu mengetahui pemahaman dan kecakapan para siswa/siswi SMA dalam memodelkan persoalan-persoalan matematika yang sederhana atau yang sering terjadi dalam kehidupan sehari-hari sudah sangat baik.

\section{KESIMPULAN}

Dari pembahasan diatas kami mengambil 5 soal dalam menyelesaikan pemodelan matematika. Pemodelan matematika merupakan bidang matematika yang berusaha untuk merepresentasi dan menjelaskan sistem-sistem fisik atau masalah yang nyata ke dalam pernyataan matematika, sehingga diperoleh pemahaman dari persoalan yang nyata ini menjadi lebih tepat. Dengan menyebar quesioner yang berisi 5 soal pemodelan matematika dan terdapat 6 siswa/i SMA responden. Pada soal nomor 1, 3, 4, 5 seluruh siswa/i SMA menjawab dengan benar dengan persentase 100\%. Dan pada soal nomor 2 ada dua orang siswa/i SMA yang menjawab salah dengan persentase 66,7\%. Dari jawaban siswa/i SMA terdapat kesalahan saat menghitung dikarenakan siswa/i kurang teliti dalam mengelompokkan data dan menggunakan rumus yang tidak sesuai dengan soal.

Dengan demikian, kita dapat mengetahui pemahaman siswa/i SMA dalam memodelkan persoalan matematika yang sederhana sudah sangat baik. Dalam menguasai materi pemodelan matematika dibutuhkan pemahaman yang baik untuk tetap mampu memodelkan segala bentuk permasalahan dengan tepat, oleh karena itu para siswa diharapkan agar tetap melatihnya untuk memperdalam kemampuan analisis yang tajam dalam memodelkan segala bentuk permasalahan yang nyata dalam kehidupan sehari-hari ke dalam pemodelan matematika. 


\section{DAFTAR PUSTAKA}

Prastowo, A. (2012). Metode penelitian kualitatif dalam perspektif rancangan penelitian. Yogyakarta: Ar-Ruzz Media.

Suwanto, F. R., Tobondo, Y. V., \& Riskiningtyas, L. (2017). Kemampuan Abstraksi dalam Pemodelan Matematika. In Seminar Matematika dan Pendidikan Matematika (pp. 301-306).

Widowati, W., \& Sutimin, S. (2007). Pemodelan Matematika.

Ang, K. C. (2001). Teaching mathematical modelling in Singapore schools. The Mathematics Educator, 6(1), 63-75.

Kemendikbud. (2016). Peraturan Menteri Pendidikan dan Kebudayaan Nomor 22 Tahun 2016 tentang Standar Proses Pendidikan Dasar dan Menengah, Menteri Pendidikan dan Kebudayaan.

Maaß, K. (2006). What are modelling competencies? ZDM - International Journal on Mathematics Education, 38(2), 113-142.

OECD. (2013). PISA 2015 Draft Mathematics Framework.

OECD. (2016). PISA Results 2015.

Febrian. (2016). The instruction to overcome the inert knowledge issue in solving mathematical problem.

Jurnal Gantang, 1(1), 15-22. 